\title{
PERLINDUNGAN DAN PENEGAKAN HUKUM TERHADAP KASUS KEKERASAN SEKSUAL PADA ANAK
}

\author{
Trini Handayani \\ Dosen Program Magister Ilmu Hukum dan Dosen Fakultas Hukum \\ Universitas Suryakancana \\ E-mail: trinihandayani2012@gmail.com
}

\begin{abstract}
ABSTRAK
Beberapa waktu yang lalu, penduduk Indonesia dikejutkan dengan berbagai kasus kekerasan seksual yang terjadi pada lembaga pendidikan yang notabene merupakan lembaga yang sangat dipercaya untuk membentuk karakter anak yang berbudi luhur serta sebagai harapan orang tua demi masa depan akademik anaknya. Kasus yang terjadi di luar lembaga pendidikanpun sangat mencengangkan, dengan korban lebih dari 100 (seratus) anak yang dilakukan sodomi oleh seorang yang sudah dikenal secara baik oleh korban dengan iming-iming hadiah yang tidak seberapa serta ancaman agar perbuatan tersebut tidak dilaporkan kepada siapapun oleh korban kekerasan seksual tersebut. Korban maupun keluarga korban menunda laporan ke pihak yang berwajib dikarenakan kekerasan seksual tersebut dianggap sebagai aib keluarga, sehingga jatuh korban yang sangat banyak.
\end{abstract}

Kata kunci: Kekerasan Seksual, Korban, Anak, dan Aib Keluarga.

\begin{abstract}
Few times ago, the Indonesian people shocked by sexual abuse case that occurred in educational institutions which was incidentally very trusted institution in building the children's characters and the parental expectations for their children's academic future. Cases that occurred outside the educational institution also very surprising, it was claimed more than 100 (one hundred) children were sodomized by a person who has well known by the victims. By promising cheap prize and by giving treatment so that they would not report as the victims of sexual violence to anyone. Victims and families delay in reporting to the police because they thought that sexual violence is considered a family disgrace, so there are a lot of victims.
\end{abstract}

Keywords: Sexual Abuse, Victim, Child, and Family Disgrace.

\section{PENDAHULUAN}

Anak merupakan kelompok yang lemah dan rentan sehingga memerlukan perlindungan agar hak-haknya dapat terpenuhi. Perlindungan terhadap anak Indonesia bertujuan agar anak dapat tumbuh dan berkembang secara optimal.
Tantangan di dalam perlindungan anak di Indonesia adalah dengan mewujudkan pemenuhan hak anak namun sekaligus dalam waktu yang bersamaan mampu memberikan perlindungan kepada anak dari bahaya yang mengintai mereka, yang pada akhirnya dapat menjauhkan 
anak dari ancaman perampasan hak anak.

Perlunya langkah-langkah afirmatif untuk perlindungan anak sebagai kelompok yang lemah dan rentan. Tanggung jawab perlindungan anak terletak pada orang tua, maka orang tualah yang menjadi ujung tombak perlindungan anak sebagaimana tercantum dalam Undang-Undang tentang Hak Asasi Manusia Pasal 26 ayat (2) yang berbunyi, "orang tua mempunyai hak pertama untuk memilih jenis pendidikan yang akan diberikan pada anaknya", artinya bahwa orang tua yang memutuskan tentang informasi maupun pendidikan yang terbaik bagi anak-anaknya ini sejalan dengan Undang-Undang Nomor 23 Tahun 2002 sebagaimana diubah menjadi UndangUndang Nomor 35 Tahun 2014 tentang Perlindungan Anak Pasal 10 yang menyatakan bahwa "setiap anak berhak menyatakan dan didengar pendapatnya, menerima, mencari, dan memberikan informasi sesuai dengan tingkat kecerdasan dan usianya demi pengembangan dirinya sesuai dengan nilai-nilai kesusilaan dan kepatutan".

Masa depan bangsa Indonesia terletak pada pundak anak-anak Indonesia saat ini, tetapi masih banyak anak-anak yang belum terpenuhi haknya sebagai anak. Hak anak yang belum terpenuhi antara lain adalah hak dasar anak. Hak dasar yang dimaksud adalah hak untuk mendapatkan kelangsungan hidup, hak untuk tumbuh kembang secara optimal, maupun hak untuk mendapat perlindungan. Di sisi lain, anak tidak pernah minta untuk dilahirkan atau ketika ia terlahir di kemudian hari beberapa diantaranya menjadi pemuas nafsu bagi oknum yang tidak bertanggung jawab. ${ }^{1}$

Kasus kekerasan seksual di Indonesia baik di dalam lembaga pendidikan maupun di luar lembaga pendidikan dengan pelaku yang sudah sangat dikenal oleh korban. Jumlah korban yang sedemikian fantastis dengan korban semuanya adalah anak-anak yang merupakan kelompok rentan.

\section{Ketua Komnas PA Arist Merdeka}

Sirait, mengatakan pada 2014 dan 2015, kasus kekerasan seksual terhadap anak mencapai lebih dari 50 (lima puluh) persen dari seluruh kasus kekerasan yang ada. Pada 2014, 52 (lima puluh dua) persen dari 4.638 (empat ribu enam ratus

1 I Gede Arya B. Wiranata, dalam (Ed). Muladi, Hak Asasi (Anak) dalam Realitas Quo Vadis? dalam kumpulan naskah Hak Asasi Manusia (hakekat, Konsep dan Implikasinya dalam perspektif Hukum dan Masyarakat), Refika Aditama, Bandung, 2005, hlm. 227. 
tiga puluh delapan) kasus merupakan kekerasan seksual terhadap anak. Tahun berikutnya, 58 (lima puluh delapan) persen kasus kekerasan seksual kepada anak dari 6.726 (enam ribu tujuh ratus dua puluh enam) kasus kekerasan," kata

\section{Arist kepada Republika.co.id. ${ }^{2}$}

Kekerasan seksual yang menimpa anak-anak Indonesia bukan saja terjadi di wilayah-wilayah yang rawan kekerasan tetapi juga terjadi di wilayah yang seharusnya memberikan perlindungan terhadap anak seperti di lingkungan keluarga, lingkungan pendidikan anak seperti sekolah, dan lingkungan kesehatan seperti ruang pemeriksaan pasien. Pelaku kekerasan seksual terhadap anak juga tidak hanya dilakukan oleh orang lain yang tidak dikenali, namun juga dilakukan oleh orang-orang yang dikenali, dekat, dan dipercaya anak, seperti keluarga, guru, dokter, teman, dan bahkan oleh aparat pemerintah seperti polisi. Ini menandakan anak-anak terancam keselamatannya dan berada di posisi sangat rentan di hampir semua wilayah sosial yang tersedia.

\footnotetext{
2 Kekerasan Seksual Dominasi Kasus Kekerasan terhadap Anak, nasional.republika.co.id , News , Nasional, diakses tanggal 2 Maret 2017
}

Tingginya kasus kekerasan seksual pada anak menggambarkan rendahnya perhatian pemerintah terhadap permasalahan ini. Kekerasan seksual terhadap anak merupakan pelanggaran Hak Asasi Manusia (HAM) berat dan harus ditempatkan sebagai kejahatan luar biasa (extraordinary crime) karena kerusakan yang disebabkannya telah mengancam masa depan generasi bangsa. Kekerasan seksual terhadap anak berarti juga telah merusak aset yang paling penting dan berharga dari negara, karena masa depan negara digantungkan pada anak-anak di masa sekarang.

Data dari Program Pelayanan Terpadu terhadap Perempuan dan Anak (P2TP2A) Kabupaten Cianjur Tahun 2014 dengan anak sebagai korban (usia 18 tahun kurang) merupakan korban terbanyak. Dari seluruh kekerasan terhadap perempuan dan anak, yaitu sejumlah 179 (seratus tujuh puluh sembilan) kasus, sebanyak 145 (seratus empat puluh lima) kasus terjadi pada anak. Apabila dipersentasekan, sebesar $81 \%$ (delapan puluh satu persen) kasus tersebut terjadi pada anak. Dari kasuskasus tersebut, kasus sodomi merupakan 
kasus terbanyak, yaitu sebesar 59 (lima puluh sembilan) kasus. ${ }^{3}$

Sanksi pidana kasus kekerasan seksual terhadap anak seharusnya tidak hanya berpijak pada Kitab UndangUndang Hukum Pidana (KUHP) dan undang-undang tentang Perlindungan Anak, tetapi juga dapat dikenakan sanksi pidana sesuai dengan Undang-Undang Nomor 39 Tahun 1999 tentang Hak Asasi Manusia. Apalagi melihat dampak dari kekerasan seksual yang sangat luar biasa, tidak hanya terjadinya kekerasan fisik maupun kerusakan organ reproduksinya, tetapi dampak psikologis yang mengancam masa depan anak sebagai generasi penerus bangsa.

\section{II.PEMBAHASAN}

\section{A. Perlindungan dan Penegakan}

\section{Hukum terhadap Kasus Kekerasan}

Seksual pada Anak

Sebagaimana dalam ketentuan Pasal 34 Undang-Undang Dasar Tahun 1945 negara mempunyai kewajiban untuk melindungi harkat dan martabat anak, ketentuan ini berimplikasi terhadap keharusan negara dalam memberikan

3 Sumber data: rekapitulasi data korban kekerasan terhadap perempuan dan anak Tahun 2014., Laporan P2TP2A Kabupaten Cianjur perlindungan yang maksimal terhadap anak. Menurut Pasal 1 ayat (1) UU 23/ 2002 anak adalah seorang yang belum berusia delapan belas tahun termasuk anak yang masih dalam kandungan. ${ }^{4}$

Adanya kesepakatan berbagai bangsa bahwa persoalan anak ditata dalam suatu wadah yang disebut UNICEF (United International Children Educational of Fund). Di Indonesia, anak dikelompokkan sebagai kelompok rentan selain orang yang berusia lanjut, fakir miskin, wanita hamil dan penyandang cacat. Ini sejalan dengan UU 39/1999 Pasal 5 ayat (3) disebutkan bahwa kelompok rentan adalah orang usia lanjut, anak-anak, fakir miskin, wanita hamil dan penyandang cacat.

Perlindungan anak adalah segala kegiatan untuk menjamin dan melindungi anak dan hak-haknya agar dapat hidup, tumbuh, berkembang dan berpartisipasi secara optimal sesuai dengan harkat dan martabat kemanusiaan serta mendapat perlindungan dari kekerasan dan diskriminasi demi terwujudnya anak Indonesia yang berkualitas, berakhlak mulia dan sejahtera. $^{5}$

4 Undang-Undang Dasar 1945 dan UndangUndang Nomor 23 tahun 2002.

5 I Gede Arya B. Wiranata, dalam (Ed). Muladi, Hak Asasi... Op Cit, hlm. 231-233. 
Dalam Pasal 3 UU 23/2002 jo UU $35 / 2014$ mengandung aspek penting yaitu: terjamin dan terpenuhinya hak-hak anak; terpenuhinya harkat dan martabat kemanusiaan; perlindungan anak dari kekerasan dan diskriminasi; terwujudnya anak yang berkualitas, berakhlak mulia dan sejahtera. Sedangkan prinsip dasar konvensi hak-hak anak meliputi: nondiskriminasi; kepentingan yang terbaik bagi anak; hak untuk hidup, kelangsungan hidup dan perkembangan; penghargaan terhadap pendapat anak.

Dalam Pasal 59 UU 23/2002 jo UU 35/2014, dijelaskan bahwa pemerintah dan lembaga negara lainnya berkewajiban dan bertanggung jawab untuk memberikan perlindungan khusus, yaitu: anak dalam situasi darurat; anak yang berhadapan dengan hukum; anak dari kelompok minoritas dan terisolasi; anak tereksploitasi secara ekonomi dan atau seksual; anak yang diperdagangkan; anak yang menjadi korban penyalahgunaan NAPZA; anak korban penculikan, penjualan dan perdagangan; anak korban kekerasan baik fisik dan atau mental anak yang menyandang cacat; dan anak korban perlakuan salah dan penelantaran. ${ }^{6}$
Perlindungan khusus bagi anak yang menjadi korban tindak pidana sesuai dengan Pasal 64 ayat (3) yaitu: upaya rehabilitasi baik dalam lembaga maupun di luar lembaga; upaya perlindungan dari pemberitaan identitas melalui media massa dan untuk menghindari labelisasi; pemberian jaminan keselamatan bagi saksi korban dan saksi ahli baik fisik, mental maupun sosial; memberikan aksesibilitas untuk mendapatkan informasi mengenai perkembangan perkara. ${ }^{7}$

Jenis-jenis kekerasan terhadap anak yaitu:

1. Fisik (berupa: tendangan, pukulan, jambakan, tinju, tamparan, lempar benda, meludahi, mencubit, merusak, membotaki, mengeroyok, menelanjangi, push up berlebihan, menjemur, membersihkan toilet, lari keliling lapangan yang berlebihan/ tidak mengetahui kondisi siswa, menyundut rokok, dll.);

2. Verbal (mencaci maki, mengejek, memberi label/ julukan jelek, mencela, memanggil dengan nama bapaknya, mengumpat, memarahi, meledek, mengancam, dll.);

3. Psikis (pelecehan seksual, memfitnah, menyingkirkan, mengucilkan,

\footnotetext{
7 Undang-Undang Nomor 23 Tahun 2002, tentang Perlindungan Anak Pasal 64.
} 
mendiamkan, mencibir, penghinaan, menyebarkan gosip). ${ }^{8}$

Menurut data P2TP2A Kabupaten Cianjur tahun 2014, data korban kekerasan pada anak meliputi trafficking sebesar 11 (sebelas) anak, kemudian persetubuhan 69 (enam puluh sembilan) anak, kekerasan dalam rumah tangga 4 (empat) anak, sodomi 59 (lima puluh sembilan) anak, ini berarti bahwa korban kekerasan kepada anak didominasi pada kekerasan seksual, baik perkosaan maupun sodomi.

\section{B. Penegakan Hukum}

Menurut Cherryl Miller terdapat

5 (lima) tipe kekerasan di sekolah yaitu:

1. Physical bullying like, causing physical injuries, stealing, punching, shoving, slapping, debagging, wedges, attacking, school pranks, teasing and abusing, fighting .

2. Emotional bullying like, spreading malicious rumors about people, keeping certain people out of "group", getting certain people to "gang up" on others, ignoring people on purpose, harassment, provocation, whispering to another in front of someone - whispering campaign, keeping secret away from a so-called friend.

3. Verbal bullying like, directing foul language at the target, name calling, commenting negatively on someone

8 Neni Sholihat, Definisi Bullying, https://nsholihat.wordpress.com/tag/definis i-bullying/, diunduh tanggal 18 Maret 2015. looks, clothes, body etc. (personal abused), tormenting, harassment.

4. Cyber-Bullying like, sending meanspirited text, e-mail, or instant messages, posting inappropriate pictures or message about other in blogs or on web sites, using someone else's user name to spread rumors or lies about someone.

5. Sexual bullying is "any bullying behaviour, whether physical or nonphysical, that is based on a person's sexuality or gender. It is when sexuality or gender is used as a weapon by boys or girls towards other boys or girls - although it is more commonly directed at girls. It can be carried out to a person's face, behind their back or through the use of technology". 9

Kejahatan terhadap kemanusiaan (crimes against humanity) merupakan istilah yang digunakan oleh Persatuan Bangsa-Bangsa (PBB). Di dalam Pasal 6 (c) Piagam Mahkamah Militer Internasional Nuremberg dinyatakan bahwa "kejahatan terhadap kemanusiaan diartikan sebagai tindakan kejahatan untuk melakukan pembunuhan, pemusnahan, perbudakan, deportasi (pengasingan, pengiriman kembali ke tempat asal) dan tindakan lainnya yang tidak manusiawi yang ditujukan terhadap penduduk sipil sebelum atau selama berlangsungnya peperangan atau penganiayaan yang didasarkan pada latar

9 Cherryl Miller, Bullying: Definition Effects, Characteristics, and Types, printed in USA, LVOW03s1426160214. 
belakang politik, rasial atau agama dalam pelaksanaan hukuman atau dalam kaitannya dengan sesuatu kejahatan yang berada dalam yurisdiksi mahkamah yang dilakukan, apakah merupakan pelanggaran dengan hukum nasional suatu negara". ${ }^{10}$

Sedangkan menurut UndangUndang Nomor 26 Tahun 2000 tentang Pengadilan Hak Asasi Manusia (HAM) Pasal 9 berbunyi: Kejahatan terhadap kemanusiaan sebagaimana dimaksud Pasal 7 huruf $b$ adalah salah satu perbuatan yang dilakukan sebagai bagian dari serangan yang meluas atau sistematis yang diketahuinya bahwa serangan tersebut ditujukan secara langsung terhadap penduduk sipil, berupa: Pembunuhan; Pemusnahan; Perbudakan; Pengusiran atau pemindahan penduduk secara paksa; Perampasan kemerdekaan atau perampasan kebebasan fisik lain secara sewenang-wenang yang melanggar asasasas ketentuan pokok hukum internasional; Penyiksaan; Perkosaan, perbudakan seksual, pelacuran secara paksa, pemaksaan kehamilan, pemandulan atau sterilisasi secara paksa

10 Soemarjo Surjokusumo, Yurisdiksi Pengadilan HAM Nasional dalam Refleksi Dinamika Hukum, Perum Percetakan Negara RI, 2008, hlm. 268. atau bentuk-bentuk kekerasan seksual lain yang setara; Penganiayaan terhadap suatu kelompok tertentu atau perkumpulan yang didasari persamaan paham politik, ras, kebangsaan, etnis, budaya, agama, jenis kelamin atau alasan lain yang diakui secara universal sebagai hal yang dilarang menurut hukum internasional; Penghilangan secara paksa; atau Kejahatan apartheid. ${ }^{11}$

Selanjutnya pada Pasal 40, berbunyi: Setiap orang yang melakukan perbuatan sebagaimana dimaksud dalam Pasal 9 huruf $g$, h atau i dipidana dengan pidana penjara paling lama 20 (dua puluh) tahun dan paling singkat 10 (sepuluh) tahun. Pasal 40 ini dapat dikenakan untuk pelaku perdagangan orang yang sering menggunakan modus 'perkosaan', perbudakan seksual, pelacuran secara paksa, pemaksaan kehamilan, pemandulan atau sterilisasi secara paksa atau bentuk-bentuk kekerasan seksual lainnya yang setara. ${ }^{12}$

Salah satu dampak kekerasan seksual kepada anak adalah adanya penyimpangan seksual sebagaimana dijelaskan oleh Edmundo Oliveira

11 Undang-Undang Nomor 26 Tahun 2000 tentang Pengadilan Hak Asasi Manusia Pasal 9.

12 Henny Nuraeny, Tindak Pidana Perdagangan Orang-Kebijakan Hukum Pidana dan Pencegahannya, Sinar Grafika, Bandung, 2011, hlm. 139. 
dalam buku Victimology and Criminal Law:

This involves psychosexual dysfunction resulting from conflicts that lead to: Sexual interest for a person of the same sex; Practices of sexual acts not habitually associated with coitus; Coitus performed under strange circumstances.

From of sexual deviancy may include: Homosexuality- sexual attraction for a person of the same sex, with male homosexuality being called uranism, while female called lesbism; Pedophillia- sexual attraction for a child. ${ }^{13}$

Kekerasan seksual pada anak, baik pemerkosaan maupun sodomi, merupakan kejahatan yang menyangkut nyawa, tubuh dan kesehatan. Pada kejahatan tersebut, mutlak diperlukan bantuan tenaga ahli seorang dokter yang berkompeten terhadap bidang tersebut yang dituangkan ke dalam Visum et Repertum.

Pengumpulan barang bukti pada kasus kejahatan seksual berupa pengumpulan, penyimpanan dan pengiriman air mani, barang bukti yang mengandung bercak harus dikeringkan sebelum dikirim. Bercak dapat diambil dari lubang-lubang tubuh manusia, yaitu lubang vagina, dubur (pada kasus

13 Edmundo Oliveira, Victimology and Criminal Law, University Press of America, Maryland, 2008, page. 62-63. sodomi), rongga mulut (pada kasus fellatio, hubungan kelamin melalui mulut), sediaan diambil dari berbagai tempat dalam rongga mulut. ${ }^{14}$

Sehubungan dengan dampak tindak pidana kekerasan seksual dengan korban anak menimbulkan dampak yang dapat mempengaruhi masa depan bangsa Indonesia, pelakunya harus dihukum berdasarkan peraturan yang berlaku, yaitu sesuai dengan UU 23/2002 jo UU 35/2014 Pasal 81 dan 82, Kitab UndangUndang Hukum Pidana (KUHP) Pasal 287. Sedangkan memaksa seseorang melakukan hubungan kelamin sesama jenis, ancaman pidananya 5 (lima) tahun penjara sebagaimana ketentuan Pasal 292 KUHP.

Dilihat dari isinya, Pasal 81 ayat (1) UU 23/2002 jo UU 35/2014 berisi setiap orang yang dengan sengaja melakukan kekerasan atau ancaman kekerasan memaksa anak melakukan persetubuhan dengannnya atau dengan orang lain, dipidana dengan pidana penjara paling lama 15 (lima belas) tahun dan paling singkat 3 (tiga) tahun dan denda paling banyak Rp300.000.000,00 (tiga ratus juta

14 Abdul Mun'in Idris, Penerapan IImu Kedokteran Kehakiman dalam Proses Penyidikan, Sagung Seto, Jakarta, 2008, hlm. 120-121. 
rupiah) dan paling sedikit persetubuhan; menentukan adanya Rp60.000.000,00 (enam puluh juta tanda-tanda kekerasan; memperkirakan rupiah).

Sementara, Pasal 82 UU23/2002 jo UU 35/2014 berbunyi setiap orang yang dengan sengaja melakukan kekerasan atau ancaman kekerasan, memaksa, melakukan tipu muslihat, serangkaian kebohongan, atau membujuk anak untuk melakukan atau membiarkan dilakukan perbuatan cabul, dipidana dengan pidana penjara paling lama 15 (lima belas) tahun dan paling singkat 3 (tiga) tahun dan denda paling banyak $\mathrm{Rp}$ 300.000.000,00 (tiga ratus juta rupiah) dan paling sedikit Rp 60.000.000,00 (enam puluh juta rupiah). KUHP Pasal 287 ayat (1) menyebut barang siapa bersetubuh dengan seorang wanita di luar perkawinan, padahal diketahuinya atau sepatutnya harus diduganya bahwa umumnya belum lima belas tahun, atau kalau umurnya tidak jelas, bawa belum waktunya untuk dikawin, diancam dengan pidana penjara paling lama sembilan tahun.

Pada Bab XIV KUH Pidana, dijelaskan tentang kejahatan kesusilaan. Perlunya Ilmu kedokteran Kehakiman dalam kasus kejahatan seksual terkait dengan fungsi penyelidikan ditujukan kepada: menentukan adanya tanda-tanda umur; dan menentukan pantas tidaknya korban buat dikawin. ${ }^{15}$

\section{Kemudian Pasal 292 KUHP} menyebut orang dewasa yang melakukan perbuatan cabul dengan orang lain sesama kelamin, yang diketahuinya atau sepatutnya harus diduganya belum dewasa, diancam dengan pidana penjara paling lama 5 (lima) tahun. Mengacu pada hukuman pidana penjara dan denda, terutama Pasal 81 ayat (1) dan Pasal 82 pada Undang-Undang Perlindungan Anak, ancaman terhadap tindak kejahatan kekerasan seksual tergolong keras.

Apabila pelaku kekerasan seksual adalah anak, usia antara 14 (empat belas) tahun sampai dengan kurang dari 18 (delapan belas) tahun, menurut UndangUndang Nomor 11 Tahun 2012 tentang Sistem Peradilan Pidana Anak, Pasal 5 ayat (3) menjelaskan bahwa dalam Sistem Peradilan Pidana Anak, wajib diupayakan diversi. Pengertian diversi menurut Pasal 1 angka 7 UU 11/2012, adalah pengalihan penyelesaian perkara Anak dari proses peradilan pidana ke proses di luar peradilan pidana.

15 Abdul Mun'im Idris, Penerapan Ilmu ... Ibid, hlm. 113. 
Selanjutnya di dalam Pasal 6 UU 11/ 2012 menjelaskan tujuan diversi adalah: mencapai perdamaian antara korban dan anak, menyelesaikan perkara anak di luar proses peradilan, menghindarkan anak dari perampasan kemerdekaan, mendorong masyarakat untuk berpartisipasi, dan menanamkan rasa tanggung jawab kepada anak.

Persyaratan diversi pada anak tercantum dalam Pasal 7 ayat (2), diversi dilaksanakan dalam hal tindak pidana yang dilakukan: a. diancam dengan pidana penjara di bawah 7 (tujuh) tahun; dan b. bukan merupakan pengulangan tindak pidana. 16

Dalam Pasal 4 UU 39/1999 disebutkan bahwa manusia mempunyai hak untuk hidup, hak untuk tidak disiksa, hak kebebasan pribadi, pikiran dan hati nurani, hak beragama, hak untuk tidak diperbudak, hak untuk diakui secara pribadi dan persamaan di hadapan hukum, dan hak untuk tidak dituntut atas dasar hukum yang berlaku surut adalah hak asasi manusia yang tidak dapat dikurangi dalam keadaan apapun dan oleh siapapun.

Selanjutnya dalam Pasal 58 tercantum:

16 Undang-Undang Nomor 11 Tahun 2012 tentang Sistem Peradilan Pidana Anak.
(1) Setiap anak berhak untuk mendapatkan perlindungan hukum dari segala bentuk kekerasan fisik atau mental, penelantaran, perlakuan buruk, dan pelecehan seksual selama dalam pdpengasuhan orang tua atau walinya, atau pihak lain manapun yang bertanggungjawab atas pengasuhan;

(2) Dalam hal orang tua, wali, atau pengasuh anak melakukan segala bentuk penganiayaan fisik atau mental, penelantaran, perlakuan buruk, dan pelecehan seksual termasuk pemerkosaan, dan atau pembunuhan terhadap anak yang seharusnya dilindungi maka harus dikenakan pemberatan hukuman.

Apabila dianalisis kasus-kasus kekerasan seksual yang terjadi di Indonesia dilakukan oleh orang yang sudah dikenal korban, bahkan ada yang dilakukan oleh guru yang bersangkutan, karyawan sekolah dimana korban menuntut ilmu, ini berarti bahwa pelaku dapat bertindak sebagai pihak lain manapun yang bertanggungjawab atas pengasuhan di sekolah dan atau di pesantren. Sesuai dengan ketentuan Pasal 58 ayat (2) UU 39/1999 pelakunya harus dikenakan pemberatan hukuman. 
Sedangkan Pasal 34 UndangUndang Nomor 26 Tahun 2000 tentang Pengadilan Hak Asasi Manusia menjelaskan tentang perlindungan korban dan saksi dalam pelanggaran hak asasi manusia yang berat, selanjutnya pada Pasal 65 disebutkan tentang korban anak yang berhak memperoleh perlindungan dari kegiatan eksploitasi dan pelecehan seksual.

Pasal 34 UU 26/ 2000 berbunyi:

(1) Setiap korban dan saksi dalam pelanggaran hak asasi manusia yang berat berhak atas perlindungan fisik dan mental dari ancaman, gangguan, teror, dan kekerasan dari pihak manapun.

(2) Perlindungan sebagaimana dimaksud dalam ayat (1) wajib dilaksanakan oleh aparat penegak hukum dan aparat keamanan secara cuma-cuma.

(3) Ketentuan mengenai tata cara perlindungan terhadap korban dan saksi diatur lebih lanjut dengan Peraturan Pemerintah.

Sedangkan sanksi pidana tentang perkosaan, perbudakan seksual, pelacuran secara paksa, pemaksaan kehamilan, pemandulan atau sterilisasi secara paksa atau bentuk-bentuk kekerasan seksual lainnya yang tercantum dalam Pasal 9 huruf $(\mathrm{g})$.
Adanya perubahan UU 35/2014, hak anak sudah mulai bertambah dengan diundangkannya undang-undang yang baru ini, antara lain mendapatkan pendidikan karakter maupun pendidikan wajib 9 (sembilan) tahun.

Kejadian bullying (kekerasan/ penindasan, termasuk kekerasan seksual) sudah sangat memprihatinkan, di beberapa negara maju, bahkan terjadi kasus bunuh diri dampak dari bullying. Indonesia sebagai negara berkembang, belum ada data resmi dari berbagai tempat kejadian bullying. Pencegahan baik jangka pendek dengan memberikan terapi bagi yang sudah terkena dampak bullying maupun jangka panjang dengan melakukan berbagai aksi yang komprehensif baik di sekolah maupun di luar sekolah serta melakukan kegiatan role play dalam melawan pelaku kasus bullying.

Film Girlfight merupakan kisah nyata seorang siswa yang di-bully oleh rekannya karena prestasi yang luar biasa di sekolahnya. Dampaknya adalah yang bersangkutan tidak mau melanjutkan kuliah padahal yang bersangkutan mendapat beasiswa dari sekolah karena yang bersangkutan menyalahkan dirinya sendiri sampai mengurung diri dan tidak melaksanakan beasiswa yang diberikan 
dari salah satu universitas terkenal di negaranya.

\section{Pencegahan}

Dalam rangka pencegahan jangka panjang perlu strategi dari berbagai pihak yang terlibat, yaitu pemerintah, pihak sekolah, Lembaga Swadaya Masyarakat yang concern terhadap kasus kekerasan seksual. Pendidikan karakter perlu dilakukan di sekolah dengan cara lebih banyak memberi porsi pembelajaran praktik yang berkaitan dengan pendidikan karakter disesuaikan dengan usia ataupun tahapan sekolah dari mulai Sekolah Dasar. Selain itu, secara periodik, pihak manajemen sekolah melakukan kegiatan yang melibatkan orang tua, karyawan sekolah, guru maupun kepala sekolah sehingga lebih terbina keakraban diantara murid dengan pihak sekolah. Selain itu perlu disampaikan materi pencegahan kekerasan seksual dengan cara yang menarik, sebagai bagian dari kegiatan life skill yang dilaksanakan di sekolah maupun di luar sekolah. Materinya adalah, 4 (empat) organ yang tidak boleh dipegang oleh siapapun, kecuali oleh orang tua (ibu) dan dokter (tatkala ia sakit, dengan pendampingan orang tua). Organ tubuh tersebut adalah dada (buah dada), selangkangan (depan dan belakang) serta pantat, dengan mengetahui bahwa organ tersebut adalah organ terlarang, anak dapat melindungi ataupun menolak apabila ada seseorang yang akan melakukan percobaan kekerasan seksual. Pemahaman antisipasi apabila pelaku melakukan percobaan juga perlu disampaikan, apa yang dilakukan apabila tiba-tiba ada seseorang yang akan melakukan kekerasan seksual melalui 4 (empat) organ terlarang tersebut.

\section{PENUTUP}

Kekerasan seksual yang terjadi di Indonesia sudah sangat memprihatinkan, termasuk di Kabupaten Cianjur. Penanganan yang komprehensif dimulai dengan kebijakan pemerintah dalam membuat kebijakan untuk mencegah dan melindungi anak sebagai korban kekerasan seksual.

Apabila pelaku kekerasan seksual tersebut berusia antara 14 (empat belas) tahun sampai dengan kurang dari 18 (delapan belas) tahun dimungkinkan untuk dilaksanakan diversi asalkan perbuatan yang dilakukan mendapatkan sanksi pidana kurang dari 7 (tujuh) tahun penjara dan bukan merupakan pengulangan tindak pidana. 
Penerapan sanksi pidana bagi pelaku mempunyai masalah pada libido kekerasan seksual perlu ditambah (kelainan seksual/ hiperseksual) dapat dengan ketentuan pada undang-undang dilakukan pemandulan secara kimia serta peradilan HAM mengingat bahwa diasingkan untuk sementara waktu dampak kekerasan seksual akan melekat sampai pelaku sembuh dari seumur hidup dan mempengaruhi masa penyimpangan seksual yang menimpa depan anak yang merupakan generasi pelaku.

penerus bangsa. Apabila pelaku 


\section{DAFTAR PUSTAKA}

\section{A. Buku}

Abdul Mun'in Idris, Penerapan Ilmu Kedokteran Kehakiman dalam Proses Penyidikan, Sagung Seto, Jakarta, 2008.

Bambang Waluyo, Victimologi Perlindungan Korban dan Saksi, Sinar Grafika, Jakarta, 2012.

Cherryl Miller, Bullying: Definition Effects, Characteristics, and Types, printed in USA, LVOW03s1426160214.

Edmundo Oliveira, Victimology and Criminal Law, University Press of America, Maryland, 2008.

Henny Nuraeni, Tindak Pidana Perdagangan Orang-Kebijakan Hukum Pidana dan Pencegahannya, Sinar Grafika, Bandung, 2011.

I Gede Arya B. Wiranata, Ed. Muladi, Hak Asasi (Anak) dalam Realitas Quo Vadis? Dalam kumpulan Naskah Hak Asasi Manusia (hakekat, Konsep dan Implikasinya dalam perspektif Hukum dan Masyarakat), Refika Aditama, Bandung, 2005.

Soemarjo Surjokusumo, Yuridiksi Pengadilan HAM Nasional dalam Refleksi Dinamika Hukum, Perum Percetakan Negara RI, 2008

\section{B. Peraturan Perundang-Undangan}

Undang-Undang Dasar Republik Indonesia 1945.
Undang-Undang Nomor 1 Tahun 1946

Tentang Aturan Hukum Pidana

Undang-Undang Nomor 26 Tahun 2000 tentang Pengadilan Hak Asasi Manusia.

Undang-Undang Nomor 35 Tahun 2014 tentang Perubahan Dari UndangUndang Nomor 23 Tahun 2002, tentang Perlindungan Anak.

Instruksi Presiden Nomor 5 Tahun 2014 pada tanggal 11 Juni 2014 tentang Gerakan Nasional Anti Kejahatan Seksual terhadap Anak.

\section{Jurnal, Artikel, Makalah, Majalah, Koran, Internet, dan Lain-lain}

Data $\begin{gathered}\text { Komisi Perlindungan Anak } \\ \text { Indonesia. }\end{gathered}$

Ensiklopedia Hukum Pidana Islam Jilid IV, Ed Bahasa Dadi M. Hasan Basri, M. Zacky Mubarok, Sofiyullah Mukhlas, EdiHayat, Ed. Ilustrasi Hamzah Fansury, Tim Kharisma Ilmu, PT Kharisma Ilmu, Jakarta, tanpa tahun.

Neni Sholihat, Definisi Bullying, https://nsholihat.wordpress.com/ tag/definisi-bullying/, diunduh tanggal 18 Maret 2015.

Rekapitulasi data korban kekerasan terhadap perempuan dan anak Tahun 2014 P2TP2A Kabupaten Cianjur. 